\title{
Sustainable Energy Systems: The Strategic Role of Chemical Energy Conversion
}

\author{
Robert Schlögl ${ }^{1,2}$
}

Published online: 13 April 2016

(c) The Author(s) 2016. This article is published with open access at Springerlink.com

\begin{abstract}
In our globalized economy a multitude of energy systems are in operation. They present quite different structures and targets despite their common goal of supplying the energy needs for all societal activities reflecting the different boundary conditions of respective societies. The common quest for sustainability has given renewable electricity and "solar fuels" a high attention. The paper describes some underlying systemic aspects of integrating renewable with fossil energy and makes the point that without chemical energy conversion (CEC) this target will not be possible. A non-exhaustive list of grand challenges in CEC is derived. Some aspects of chemical energy science are discussed.
\end{abstract}

Keywords Solar fuels · Energy system · Chemical energy conversion - Water splitting - Decarbonisation

\section{Introduction}

The supply of a society with energy is a core responsibility of co-operation between politics, markets and industry. The flow of energy is controlled by few economical structures that are under only limited control of politics as exemplifies the history of oil supply to the US. The present discussion on sustainability of energy systems leaves the illusion that a modification of the energy system could be possible under democratic control. The discussion hides the fact that

Robert Schlögl

rs01@fhi-berlin.mpg.de

1 Max-Planck-Institut für Chemische Energiekonversion, Stiftstraße 34-36, 45470 Mülheim, Germany

2 Fritz-Haber-Institut der MPG, Faradayweg 4-6, 14195 Berlin, Germany the energy system is constantly under change and is controlled by phenomena that are outside the control of any single society on this planet. The energy systems change under influence of societal megatrends, of technological capabilities and under long-lasting geo-strategic evolutions. One common control variable is the price of energy that is not found by supply and demand but results from the co-operation of the phenomena listed above.

Energy supply is systemic as it comprises different sources of primary energy, different means of transportation and distribution and different end uses. This technological dimension is supplemented by dimensions of legislation and regulation, of markets and economic factors and of environmental responses of our ecosystems and of societal behaviour. All of these phenomena are interconnected by the phenomena listed above and form a system of feedback loops. It is safe to say that we have lost rational control over the energy system; we can no longer predict the response of the system following a single stimulus in any of the dimensions noted. Regulatory measures to achieve a single desirable evolution towards a single development target lead thus to multiple responses of desired and undesired nature. The consequences are quick fixes of the regulatory system causing the same effects and thus lead in historical evolution to highly complex and regionally well-differentiated systems that cannot be directed with simple measures any more. Practical everyday examples are the evolution of the petroleum price or of the prices of primary energy carriers oil, gas and coal.

Chemistry [1] and more specific catalysis science [2] are deeply involved in the energy issue as the supply with energy is to over $90 \%$ the result of molecular transformations of hydrocarbon resources. Other branches of chemistry supply the material science for the construction of energy transformation and distribution systems. Only to a 
relatively small fraction (ca. $5 \%$ ) the whole chemical industry is using energy for its transformations and as its indispensable feedstock. This leading role of chemistry is hidden under the division in chemical and petrochemical industries as well as under the fact that energy transformation is today considered widely an engineering challenge and less a matter of chemical or basic science. If we briefly recall that energy cannot be generated but only be converted from essentially oxidising $\mathrm{C}-\mathrm{H}$ and $\mathrm{C}-\mathrm{C}$ bonds into $\mathrm{CO}_{2}$ and water and if we contemplate of how well (really?) we understand the underlying heterogeneous [3-5] and homogeneous processes apart from islands of knowledge for example with internal combustion engines [6-9] for cars, then we see that there is still much room for generating knowledge leading to conceptual [10] improvement. Such science (electrochemistry, coal science [11-14], oil chemistry, solids combustion chemistry $[15,16])$ was popular in the first half of the 20th century but is not widely practiced now, possibly because of its high complexity and thus large phenomenological nature it took in its early days.

With the periodically occurring and in intensity increasing [17-20] societal quests for making the energy supply a sustainable and predictable basis of societal activity the contribution of chemistry to this endeavour has to increase $[1,10,21]$ both in volume and scope. It is interesting for chemists wishing to contribute to this area of scientific activity to contemplate over a few basic ideas and concepts of the energy system. We observe at present as in many earlier waves (oil price shocks) $[22,23]$ of scientific activity broad but short-lived activity failing to enhance our basis of technological options at al level where these could contribute to rational transformation of the energy system according to a societal target. One may be aware that such ideas were put forward many times [19, 24-28] before. The lack of political or societal drivers and the unsteadiness of political impulses have hampered any serious attempt to rationally develop an energy system beyond incremental modification. The scientific movement for the development of solar fuels [29] by artificial leaves [18, 30-32] is a large and well-supported activity that for the first time may make it form concept to practice. Its drawback is that its approach does not fit well to the already existing massive economic engagement into primary renewable electricity [33, 34] generation requiring urgently measures of integration with the existing demand structure. The author considers this integration as the biggest challenge in the near future, as failure to achieve this will create a strong backswing to fossil and conventional nuclear options damaging the idea of sustainable energy systems for a long time.

Energy integration as the actual challenge does neither devaluate the solar fuel approach requiring multiple scientific and technological elements from the solution of the integration issue nor is it in contradiction to novel grassroots approaches to the energy supply issue $[35,36]$. We need all of these approaches simultaneously. We need however, also be brave enough to measure our activities according to systemic requirements such as scalability and resource use and stop advertising our conceptual ideas as ready-made solutions for the energy challenge. This habit gives our science a reputation of unreliability and irresponsibility that harms all our essential efforts to contribute to the energy transformation with rational rather than with volatile impulses.

\section{Targets and Drivers}

One of the most critical arguments for or against any science-based modification of the energy system is the economic killing argument of "too high price". This argument inhibits all truly innovative approaches and is thus toxic for innovation. On the other hand it is essential that we keep in mind that energy solutions need to be available to all who need it. "Availability" includes also economically viable access to energy. The argument that energy technologies need to be price-competitive with the existing energy system is often used but needs a societal discourse. The uncontrolled consumption of fossil resources and the assignment of all economic risk of using energy technologies to society excluding these factors from the actual "price" need to be debated and decided. Only when a pricing system is agreed that allows comparison of current and novel approaches to energy supply on a common basis, the economics of technological options can be used as one ingredient in the evaluation of novel scientific ideas. The difficulty of estimating economic data of non-existing technologies in the absence of demonstrators and operation experience is worth a discussion on its own.

Another critical aspect to evaluation of scientific activities for the energy system is their compliance with the overall targets of the system evolution. As energy supply is systemic there is no single obvious development target. In addition, different societies have quite diverse ideas about such targets. The political method of adding many targets together is not useful for science as any decision-making or prioritisation according to complex target mixtures is not possible. To render the issue even more complex multiple "targets" are no targets but measures that may modify an energy system. The table lists some common targets and measures.

These unclear positions in the energy debate blur the challenge for science. It should be the role of science in its broader definition to develop options for the evolution of the energy system with clearly assigned strengths and weaknesses. In practice, science is faced with developing many concepts into technological options requiring steps of 
selection and prioritization due to limited resources in time and finance.

An enabler for this selection would be a clear driver set by society. Only such a driver would have the legitimate and long-term effect of shaping the evolution of the energy system through directing the scientific-technological evolution. Political agenda setting for one legislative period is unsuitable and potentially detrimental for science that is put on different tracks much faster than true insight and knowledge-based technology development can deliver reliable results. Science escapes these problems by defining in superficial manner single figure of merit criteria supporting the definition of novelty and innovation. Efficiency of solar cell systems [37-41] or onset potentials for water splitting or turnover frequency for catalytic transformations are examples of such "science drivers". Chemical stability and synthetic reproducibility are amongst the critical properties being hidden under the "innovative" single figure of merit aspect of science innovation for energy.

Such drivers make science into a sportive event focussing on single parameter "excellence". This occurs often without defining an internationally agreed method of determining the relevant numbers. The necessarily superficial character of the resulting science race reduces the chance to arrive at useful solutions that serve the given or indicated purpose. This usefulness includes scalability, material and device lifetimes and accessibility to all material resources (noble metals, complex processing). The usefulness is thus a multiple parameter optimization with compromises on the single figure of merit property. An example may be a water splitting device that is not maximal energy-efficient but long-lived and constructed from earth-abundant materials in a simple manufacturing process. Use scenarios such as stationary or mobile applications may change such compromises and lead to several parallel design strategies for one and the same device type. Accumulators are a good example for the broadness of scopes that justifies a hierarchical scientific approach starting from fundamental research followed by gradual phases of application-oriented narrowing of scope.

The following discussion abstains from such drivers and targets and tries to enumerate a list of challenges that need to be met by chemicals science in order to enable a generic sustainable energy system.

\section{Structure of Energy Systems}

Sustainability for energy in the context of chemical solutions means that such systems must close the material fluxes within the system. Only water and oxygen are exempt from this requirement as they are so abundant on earth. Closing the material cycle is not only related to energy carrier resources but also to mineral resources needed for structural and functional materials required for the energy transformation. Feedstock required for feeding the population are also excluded from the use for energy purposes.

Figure 1 shows the most simplified structure of the challenge. The imbalanced $\mathrm{CO}_{2}$ emission affects the climate on earth. The use of uneven distributed fossil energy resources impeded energy security and carries multiple risks associated with the pressures to exploit technologically challenging resources going hand in hand with environmental risks and the destruction of eco-resources such as rainforest, underwater systems or the Antarctic.

If we want to impede this we have two options that likely we need both. First we have to save energy. That means not only to become energy efficient in the way we transform free energy in final uses but also in the way, how much energy we use per person. Figure 2 shows some data for energy use and its effectiveness in conversion for Germany. Could we become more energy-efficient and reduce the losses substantially then we have much less energy pressure. Chemistry has to play multiple roles [42] here. We see that large possibilities lay in the sectors of low-temperature heat use (house heating) and in the use of fuels for mobility (part of "mechanical"). The fraction of electricity for non-mechanical uses (motors) is not large and has thus a smaller saving potential. An enormous saving potential lies in avoiding thermal energy as conversion form for the generation of electricity in Carnot machines. Could we convert material energy carriers flameless [43] into electricity (fuel cells with hydrocarbons

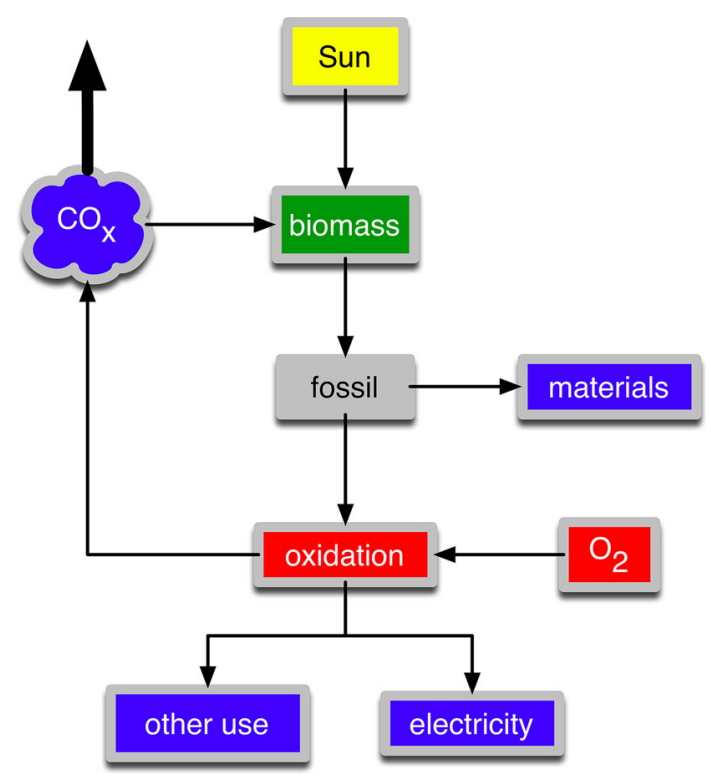

Fig. 1 Highly simplified scheme of a generic non-sustainable energy system. The material flow for $\mathrm{CO}_{2}$ remains open 


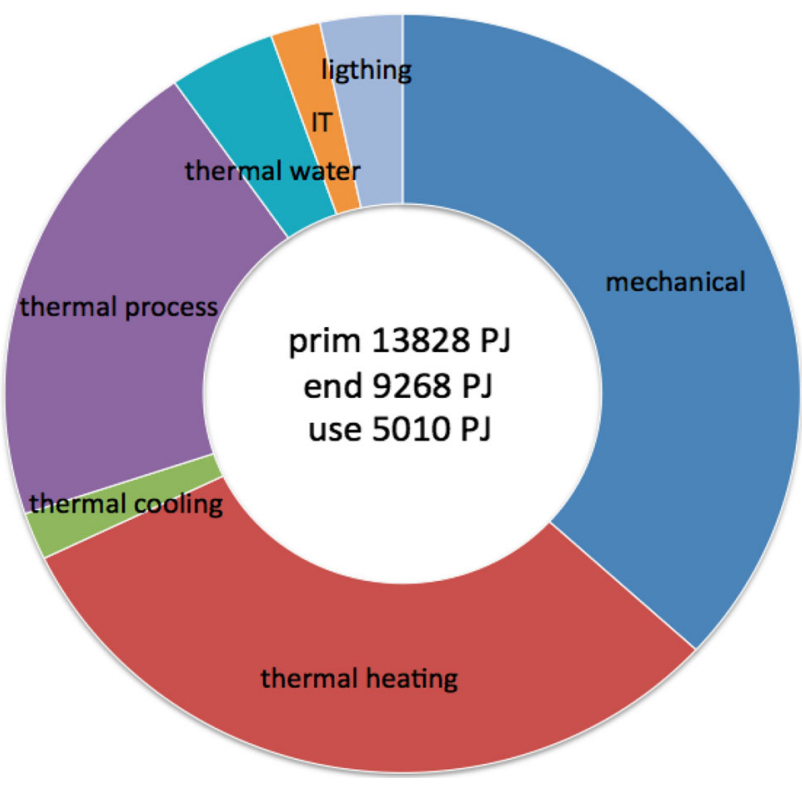

Fig. 2 Uses of energy in Germany. The absolute numbers in PJ give the primary energy consumption over all non-renewable energy carriers in Germany, its conversion into end energy (main loss production of electricity) and its use for final purposes given in the diagram. Data from BMWI energy statistics 2015 for the year 2013

or coal) then we may save a large fraction of primary energy. It is "only" the kinetics of electrode reactions and the lack of catalysts that prevent us from performing such reactions.

Figure 3 shows some data on the electricity use per person in the world. If we multiply the "first world average" of about $7000 \mathrm{kWh} / \mathrm{a}$ by the global population then we see an enormous increase in electricity generation with the related enormous use of fossil energy carriers (mostly coal) and the respective emission increase. It is outside the scope of this paper to discuss options how to reduce the specific value of energy consumption. Making chemical industry more energy-efficient is certainly useful and highly desirable as well as using LED lighting but both prototypical measures will not cure the issue. Substantial societal and economical modifications are needed here. If we cannot succeed in more reduced energy consumption per capita then even the target of stabilizing greenhouse gas emission against the increase in world population will be a difficult task. It should be stated here that the energy-efficiency as measured by the consumption of primary energy carriers against standard applications is hard to determine in the world; in Asia the energy system is less efficient than in Germany or in Europe. In both regions substantial diversity in efficiency per unit plant exist; in China massive investments improve the plant park whereas in Germany the process has come to a standstill for mainly non-technical reasons. This underlines again that technology and science alone cannot solve the energy challenge.

The second approach is to close the material fluxes in the energy system. This can be achieved by reducing the use of fossil energy carriers by replacing it with renewable energy carriers. As $\mathrm{CO}_{2}$ represents one large bio-geochemical [44] cycle on our planet, it is not necessary to remove $\mathrm{CO}_{2}$ from our energy system and "decarbonize" it. It would be sufficient to stop the increase in $\mathrm{CO}_{2}$ emission immediately and reduce the man-made emission to a substantially lower value of ca. $50 \%$ of the present emission. A large fraction towards this target comes from replacing fossil by renewable electricity and heat, the other part would require recycling of $\mathrm{CO}_{2}$ by chemical energy conversion (CEC) with hydrogen from renewable electricity. This will be discussed in detail below. Natural processes including the use of biomass can accommodate the rest and close the cycle. The advocated use of biomass [17, 45-49] as storage system against volatile renewable energy or even
Fig. 3 Consumption of electrical energy per selected country. Figures from 2012. Data from BMWI energy statistics 2015

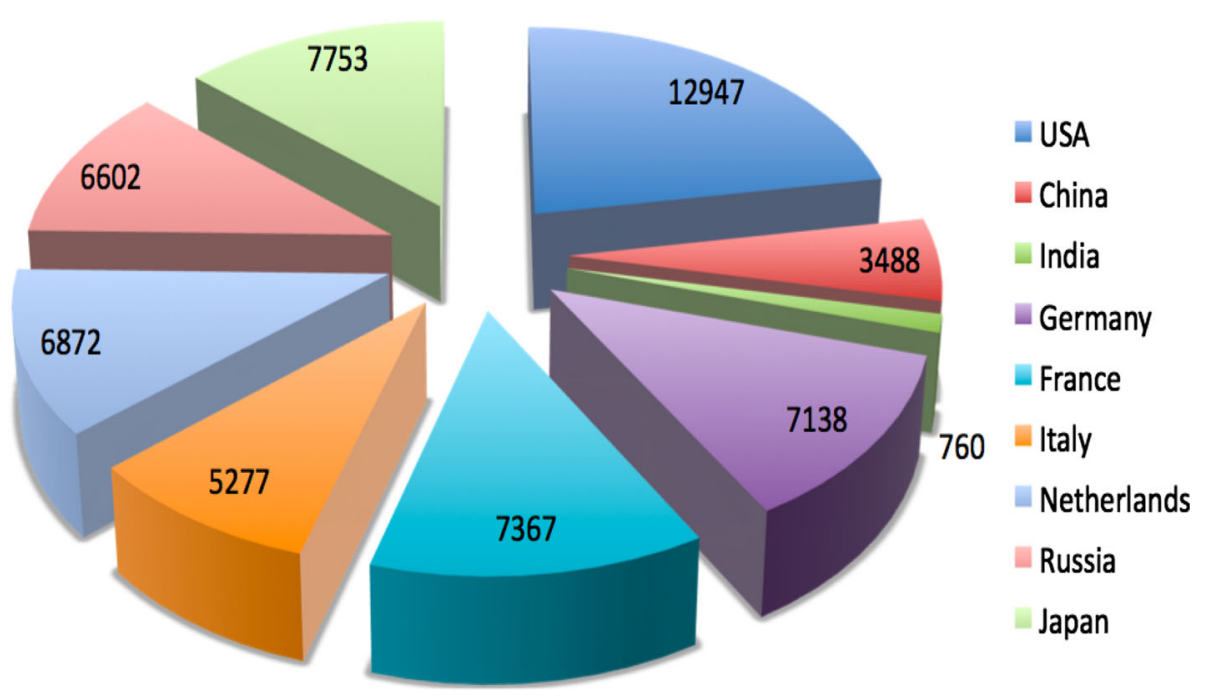


as renewable energy carrier is less-likely to meet the expectations. At present the use of biomass as resource for chemical feedstock or intermediate products is much more promising. Local uses for heating or after upgrading as transportation fuel or additive may be useful and are possible. In the longer run we see the need to use as much as possible biomass without damaging the global ecosystem stability for feeding the growing population.

We arrive at a sustainable energy system of the generic shape indicated in Fig. 4 . We recognize the increased complexity and the need for technological elements that are not available today in qualities ready to use on a world scale. We intuitively feel that the price of energy in such a system must be higher than today as the complexity of the system is larger. We do not know, however, how large this increase will be and how we evaluate its magnitude. The missing knowledge has to be provided by science which is clearly based in chemistry but which also clearly needs interdisciplinary augmentation by scientific, engineering and socio-economic disciplines. Ideally all this should happen in a concerted effort now before society takes decisions on the shape and targets of energy systems. The author is realistic

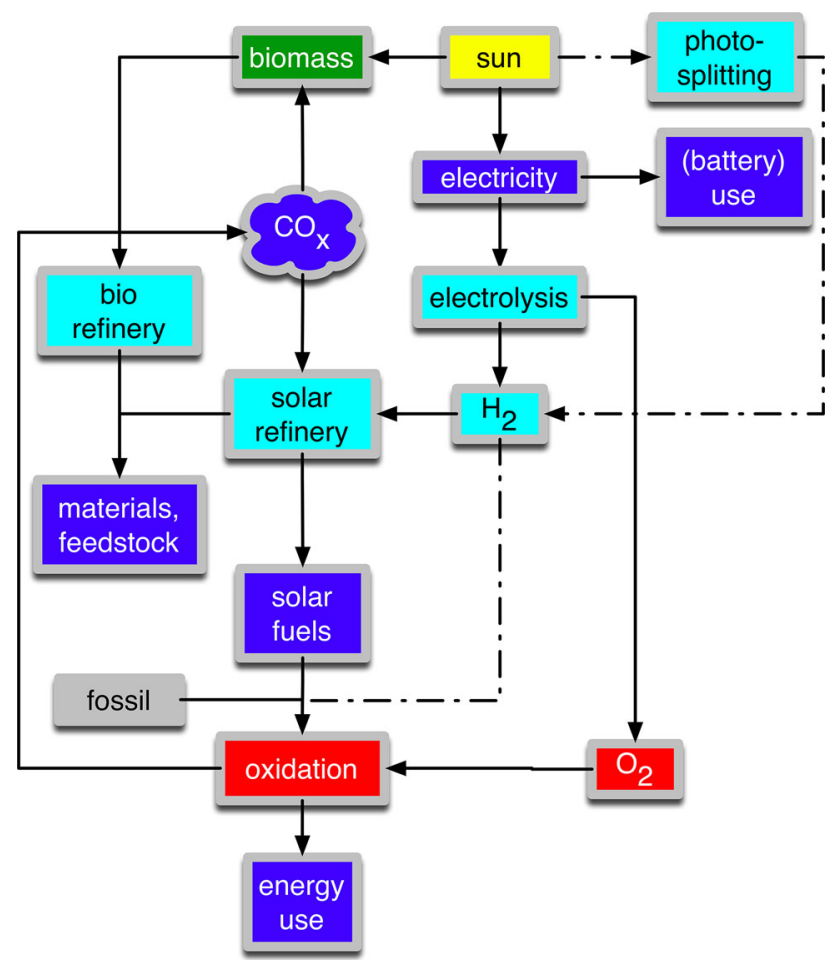

Fig. 4 A generic design of a sustainable energy system. The elements of Fig. 1 are present and augmented by additional elements needed to use sunlight directly and effectively for energy uses. The dashed lines indicate elements that may contribute in later development stages of the energy system. The light blue boxes indicate elements that are not yet existing and/or fit for world scale applications enough to see that this will not happen and science will be involved in a race with politics and economics to provide the understanding and technologies without a rational approach.

\section{Energy Science}

The necessary selection processes for scientific activities closing the gaps of knowledge and technology indicated in Fig. 4 should be based on criteria that are more solutionoriented than those selecting "interesting" science results for publication (see also section "targets and drivers"). To arrive at such criteria we need to briefly think about likely drivers of the energy transformation. Politics alone may provide impulses for change but they will not be lasting to really change the development. This can be seen in the German Energiewende as well as in the US bio energy initiative as examples. Sustained drivers come either from international legislation (see emission regulation for internal combustion engines) and/or from long-term economic feasibility of a sustainable energy system. The author suggests sticking to the latter argument and translating this target of optimized economic affordability including direct and indirect cost of using energy into criteria for technology prioritisation. This prioritization should not work on basic science and on novel approaches to sustain a continuous flow of grassroots approaches. It will, however, be necessary for the transfer science generating technology and demonstrators in dimensions required for estimating the systemic use of a suggested technology. This can only be done with few proposals. Suitable forms of co-operation between academia, industry, politics and society need to be found to minimize losses of technological options due to non-technological obstacles. Breaking it down to practical dimensions of estimation we see that beside "performance" also stability and closed material cycles are hard systemic requirements for true energy research. Scalability and manufacturability are secondary concerns as well as a minimum of systemic innovation required for rollout. All together individual scientists may use such criteria for directing their individual activities long before complex prioritization schemes are applied for large-scale funding to separate fundamental science that never requires a justification in application from energy-related activities. A core issue in energy science is the optimization of functional materials $[50,51]$. This is well recognized but in its implementation care is needed to consider the mentioned systemic boundary conditions of suitable pathways and suggestions. Many excellent performing samples $[52,53]$ prove very hard to convert into scalable reproducible materials. This important work is not valued highly in the scientific community 
but represents a critical element in arriving at true knowledge-based solution for CEC technologies.

It is noted here that chemistry contributes in many other aspects to the sustainable energy issue that are not concerned with CEC. It is beyond this text to discuss these important contributions that are in no respect less important than the CEC-catalysis aspects discussed here. The general remarks on the distinction between curiosity-driven fundamental science with relation to energy and applicationoriented science directs towards the solution of a specific problem in the energy system holds also for these other contributions of chemistry to energy science.

\section{The Big Thing First: Energy Integration}

At present we are in period of transition between systems of Figs. 1 and 4. We have invested in primary electricity generation but still use massive amounts of fossil fuels. We use sub-optimal regulatory instruments for generating the financial resources required for the hybrid operation. We thus see limited effects on the greenhouse gas emission despite the efforts in novel and now mature technologies of PV and wind energy generation. This does not say that we need no more science in the area of PV and wind energy for making them more efficient and more adaptive to largescale or decentralized applications. These activities do, however, not enable the transformation of the energy system in the foreseeable future.

The "big thing" and often not acknowledged problem is the incompatibility of fossil and renewable electricity with

Table 1 Commonly used targets in the discussion for the evolution of an energy system

\begin{tabular}{lll}
\hline $\mathrm{Nr}$ & Target & Function \\
\hline 1 & Sustainability & Target \\
2 & Supply security temporal & Target \\
3 & Supply security political & Target \\
4 & Supply security societal & Target \\
5 & Renewable energy generation & Measure \\
6 & Decarbonisation & Measure \\
7 & Societal acceptance & Measure \\
8 & Biomass utilization & Measure \\
9 & Low prize & Measure \\
10 & Energy storage technologies & Measure \\
11 & Incentives for technology introduction & Measure \\
12 & Energy efficiency measures & Measure
\end{tabular}

From an analysis of the effect of the "target" on the energy system one can discriminate designated targets in true targets and in measures enabling the energy system to reach a target. This is indicated in the row "function" respect to temporal availability (see Table 1). Renewable electricity is volatile and occurs in a temporal distribution incompatible with the energy demand structure in the "developed world". Renewable energy is no "drop in" solution for fossil or nuclear energy. As we will hardly see a significant change in demand structure within our societies we have to find scientific means [32] of equilibrating supply and demand. This has to be done not only over the electricity part of the energy system but rather over the whole system with all major sources of $\mathrm{CO}_{2}$ emission. Figure 5 shows the challenge. Divided in full load hour equivalents the demand structure of Germany serves as an example [33] for a "developed" country.

The substantial contribution of renewable electricity is also indicated. The excess curve will result if the political development targets are reached within the next two decades. We see the then enormous contribution of renewables but also the still significant undersupply and the excess with a highly unfavourable time structure (very short times with enormous surplus generation). The conceptual simple idea of taking the excess and store it for the undersupply is barely feasible in the framework discussed above due to a lack of drivers of such an economically unfavourable proposition. The very short annual use time for complex technical systems indicated in Fig. 4 and the high price of the regenerated electricity with respect to fossil electricity will impede such solution until there is no fossil energy carrier left. If we find no better solution of use the excess renewable electricity in an economical way then the rollout of renewable electricity devices will slow down enormously as soon as the capacity of the grid for volatile energy is exhausted (in Germany almost today).

The general solution for long times (more than $5 \mathrm{dec}$ ades) will be the evolution of the present situation into a stable hybrid energy supply. The very short time excess (top $600 \mathrm{~h}$ ) may be used for local thermal applications or may be discarded. The long-term excess electricity can be used for CEC applications leading to high-price products and not to secondary electricity. The undersupply will likely be compensated from fossil sources while converting a maximum of the resulting $\mathrm{CO}_{2}$ by $\mathrm{CEC}$ into molecular products. Such products can be feedstock for the chemical industry but will be more effective for climate protection and for revenue generation for the whole energy system if it is put into the transportation fuel sector.

In short, the remediation of excess electricity generation and later the replacement of fossil fuels in the materialbased parts of the energy system (transportation fuels, carbo-thermal processes, production applications) can only be achieved if we learn to convert material energy carriers in electricity and back-convert electricity into material energy carriers. This should be achieved at small energy 
Fig. 5 Schematic of the fullload hour curve of the German electricity grid (blue). The load varies between ca. 45 and $80 \mathrm{GW}$. The red curve indicates the contribution of renewable electricity in 2012. The green curve predicts the renewable contribution in 2035 according to political targets

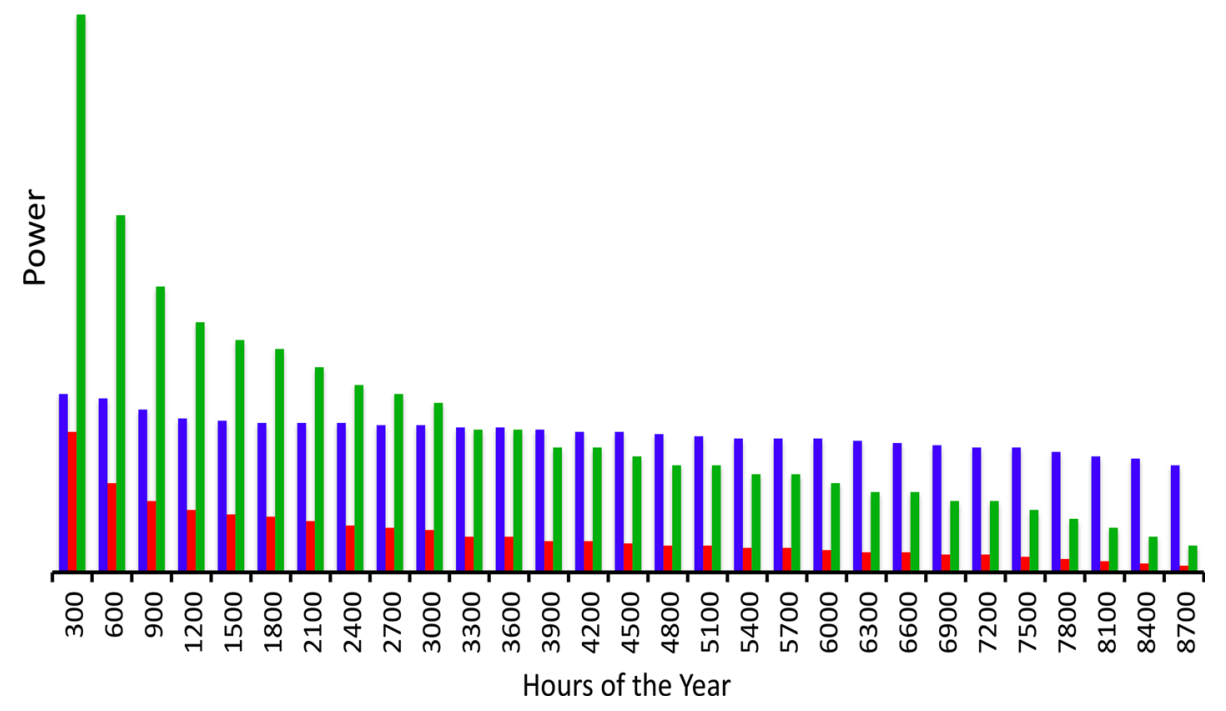

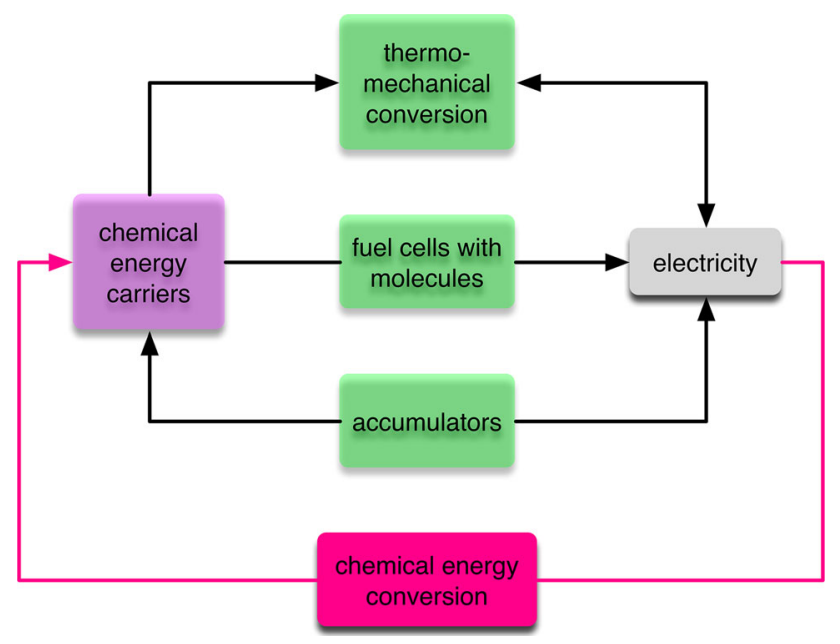

Fig. 6 Free inter-conversion between chemical energy carriers and electricity is the single critical condition for the transformation of energy systems into a sustainable mode that is based upon renewable primary electricity

losses and without the use of open material flow loops. Figure 6 schematically shows the challenge and highlights the existing solutions in addition to the chemical challenges.

The dominant lacking pathway is the conversion of electricity into material energy carriers ("solar fuels"). The most critical single process in the necessary sequence of reactions is the generation of free electrons from oxidation of oxide ions stemming from water or potentially from $\mathrm{CO}_{2}$. It is needless to say that these processes involve interface reactions and are within the domain of catalytic reactions. The contribution of molecular catalysis to these challenges considered first as heterogeneous reactions or following the examples of natural processes is yet to be evaluated. As we want to exchange free charge carriers we need in most case electrodes and thus interfaces. Unfortunately, the most important interface is that between solids and liquids which is the one where we still have enormous problems in studying and understanding chemical reactions. Our lack of ability in water splitting $[54,55]$ and battery science [56] measured against requirements of world-scale application are consequences of this fundamental deficit. But also solid-solid interfaces (electrodesolid electrolyte [57-59], carbon solid fuel cell [60]) are of low study interest possibly because of the dominating role of slow kinetic processes.

\section{The Role of Fossil Fuels}

Although it is the purpose of energy transformative processes to minimize the role of fossil fuels it should not be the prime (political) target to discourage their use. As a stabilizing agent in volatile renewable energy scenarios they are invaluable as they are energy storage systems and they are still and possibly always cheaper than synthetic solar fuels. If we reduce the rate of consumption and discard the use of environmentally harmful developments of fossil deposits (not yet on the agenda today) then we can keep the economics of the energy transformations in acceptable dimensions. Fossil fuels buy us decades of time to economize renewable technologies. Figure 5 shows us that even if we use fossil fuels without utilization of $\mathrm{CO}_{2}$ (CCU) then we will drastically reduce the $\mathrm{CO}_{2}$ emission from electricity generation. By using a strategically chosen mix between gas and coal we can arrive at a stable and strongly $\mathrm{CO}_{2}$ reduced energy supply system that is still affordable. An even better utilization would result if we replace the conventional combustion systems (power stations) by systems that can easily be switched between 
combustion and gasification [10, 61] of fossil fuels. Then we arrive at high annual runtimes for the infrastructure and gain flexible operation between generation of electricity and of synthesis gas for making transportation fuels. Figure 7 shows a resulting more detailed system characterized by a dual structure of renewable and fossil primary energy supply. The key catalytic chemistry involved is the conversion of $\mathrm{CO}_{2}$ and synthesis gas with hydrogen generated from renewable primary energy utilization [62] into platform molecules. These are methanol, methane or hydrocarbon mixtures from Fischer-Tropsch synthesis. Additional platform molecules would be higher alcohols such as ethanol, olefins and ammonia.

Such a combined generation of power and chemicals under inclusion of renewable energy makes only sense if the dimensions are correctly considered. Present concepts of $\mathrm{CO}_{2}$ utilization for chemical synthesis and polymer production [63] are useful additions to the portfolio and save energy but cannot be used to couple into tandem production of electricity and chemicals. Even the generation of all feedstock for chemical industry cannot solve this dimensional problem although it is a possible first step. The only systemic useful outlet for such a tandem production is the regime of transportation fuels $[64,65]$ with a market size large enough to accommodate the transition period and the final slow replacement of conventional fossil fuels by synthetic [66] solar fuels. This approach requires a regulatory design of the entire energy system with a common system of emission limits (as presently in use in the mobility sector) and incentives, as utilization of large amounts of primary electricity in non-electrical applications and the saving of $\mathrm{CO}_{2}$ in the non electrical sectors need to be made possible and acknowledged (taxations, feed-in systems, stability of regulations over decades of operation).

In order to give an idea about the dimensions of such an operation the quantitative situation of Germany shall be used as an example. In Fig. 8 the $\mathrm{CO}_{2}$ emissions from energy applications are shown today and after reaching targets of current energy system planning of the government [67] ("Energiekonzept"). Some of the figures given are less demanding than described in this concept to accommodate for the likely overestimation of saving/replacement potentials by biomass assumed in the concept.

If we then add the concept of carbon capture and use (CCU) as outlined in Figs. 6 and 7 then we see which carbon fluxes need to be treated. The extent to which the $\mathrm{CO}_{2}$ cycle can be closed will depend on the availability of hydrogen ex primary electricity. If we would allow the import of such hydrogen (or the export of $\mathrm{CO}_{2}$ ) from geographic areas with more beneficial conditions for renewable generation or if we convert our current practice of driving the installation of renewable electricity by the demand of the electricity sector to controlling the installation by the demand of $\mathrm{CO}_{2}$ abatement (power-to-X driven, instead electricity driven) then we can arrive at high recycle ratios.
Fig. 7 Schematic

representation of an integrated energy system utilizing a maximum of renewable energy for electricity generation. The excess renewable electricity (see Fig. 5) is used for thermal applications and for the cogeneration of hydrogen.

Conventional power stations are replaced by gasifier/burner combinations allowing flexible response of the residual fossil (waste) combustion against the electricity demand using during the other times the equipment for gasification (or for dry reforming of $\mathrm{CO}_{2}$ with methane) to arrive at synthesis gas. The light blue elements are tasks of chemistry and require still enormous efforts in research and development to be applied in grid-scale installations

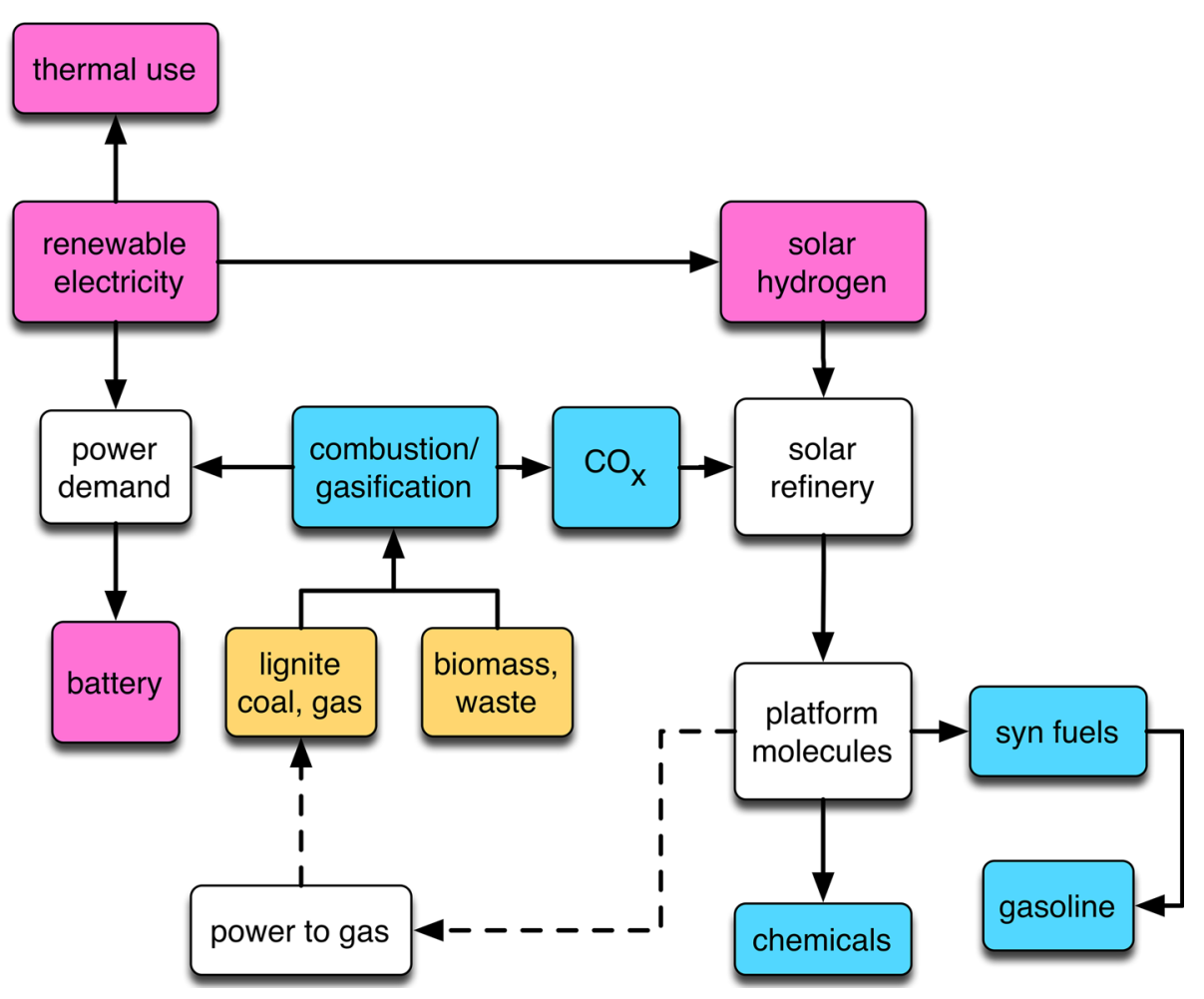


Fig. 8 Mass flow of $\mathrm{CO}_{2}$ in the German energy system. The top line indicates the emissions from the application ranges in megatons per year (data 2012). The middle line indicates the residual emissions after implementation of the "Energiekonzept". The blue components highlight the possibilities of linking electricity and CEC in order to transfer renewable energy in non-electrical parts of the energy system and simultaneously further reduce the open $\mathrm{CO}_{2}$ emission

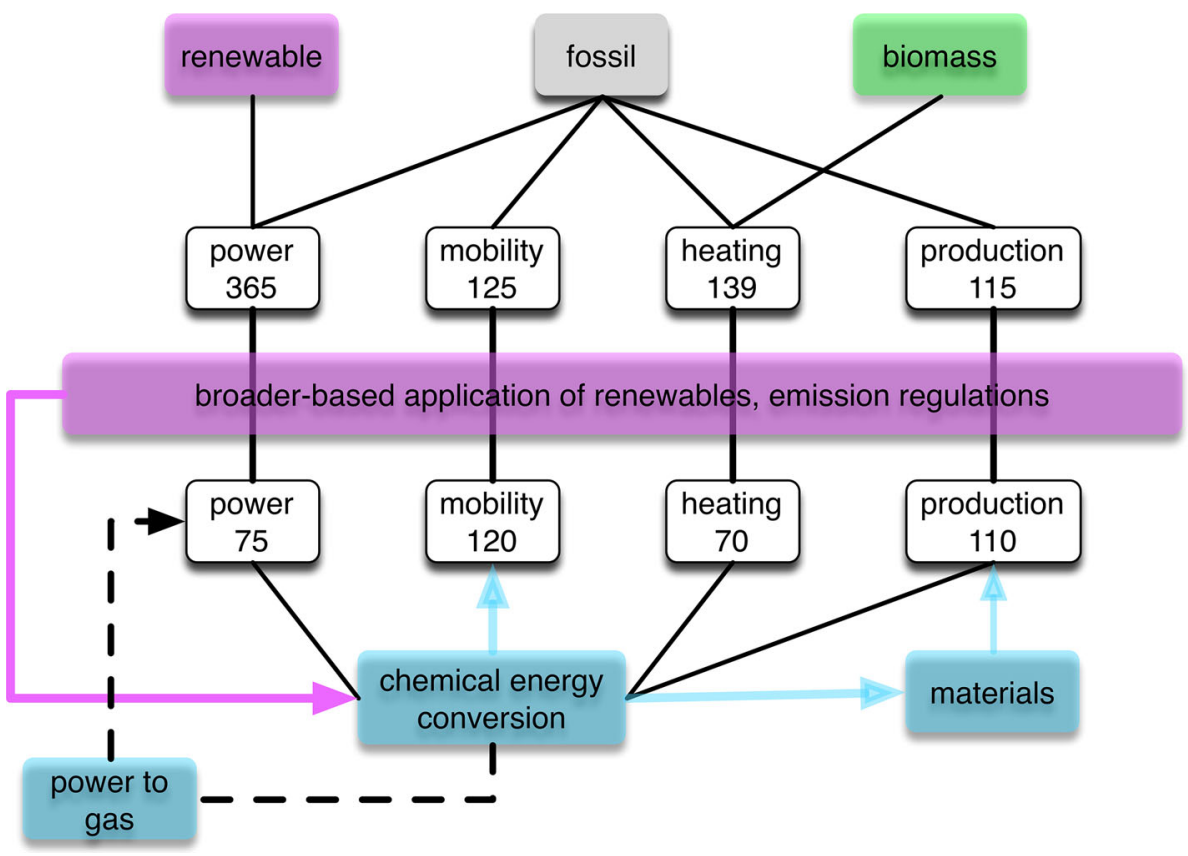

In final consequence the only remaining significant $\mathrm{CO}_{2}$ emission sources would be mobile sources with the demand of high energy density (not battery-operated city vehicles, but long distance travel, goods transportation, aviation, high-power mobile instrumentation [68]). This can be realized although we still use substantial amounts of ca. $20 \%$ fossil fuels for electricity generation. The amount is estimated such as to stabilize the system against the adverse effects of volatility or primary energy supply from the sun. Multiple factors affect the real fraction of required fossil stabilization. Among them are the design concepts of the energy system in hierarchical supply and storage solutions (central, local decentralized, local for industrial use, regional and European collaboration). It is outside the present scope to describe concepts of internationalization of such systems [33, 69-71] with trade elements and technology exports.

\section{The Chemical Toolbox of CEC}

Following the conceptual lines sketched so far we can define a list of critical chemical reactions that we must be able to perform. These are:
(1) $2 \mathrm{H}^{+} 2 \mathrm{e}^{-} \leftrightarrow \mathrm{H}_{2}$
(2) $2 \mathrm{O}^{2-} \leftrightarrow \mathrm{O}_{2}+4 \mathrm{e}^{-}$
(3) $\mathrm{CO}_{2}+4 \mathrm{H}^{+} \rightarrow \mathrm{C}^{4+}+2 \mathrm{H}_{2} \mathrm{O}$
(4) $\mathrm{C}^{4+}+2 \mathrm{H}^{+}+4 \mathrm{e}^{-} \rightarrow\left\{\mathrm{CH}_{2}\right\}$
(5) $\mathrm{C}^{4+} 4 \mathrm{e}^{-} \leftrightarrow \mathrm{C}$
(6) $\mathrm{CO}_{2}+2 \mathrm{H}^{+}+2 \mathrm{e}^{-} \leftrightarrow \mathrm{CO}$
(7) $\mathrm{CO}_{2}+3 \mathrm{H}_{2} \rightarrow \mathrm{CH}_{3} \mathrm{OH}+\mathrm{H}_{2} \mathrm{O}$
(8) $\mathrm{C}+4 \mathrm{H}^{+}+4 \mathrm{e}^{-} \leftrightarrow \mathrm{CH}_{4}$
(9) $\mathrm{CO}_{2}+\mathrm{CH}_{4} \rightarrow 2 \mathrm{CO}+4 \mathrm{H}^{+}+4 \mathrm{e}^{-}$
(10) $\mathrm{N}_{2}+3 \mathrm{H}_{2} \rightarrow 2 \mathrm{NH}_{3}$

The bi-directional arrows indicate that we are interested in the possibility to perform the reaction in either direction in order to store or retrieve free energy. All these reactions have in common that they involve activation of small molecules for which we should have a solid understanding and a rich expertise on catalyzing the respective transformations. The list is not comprehensive as it omits the formation of larger molecules of hydrocarbons only for lack of specificity.

The reactions $4,6,7,10$ are executed today in worldscale dimensions. They exhibit still substantial room for improvement as well as the combustion reactions not indicated in the equations. Both, intrinsic kinetic deficits and intricate requirements for feedstock quality and reaction apparatus present hurdles for more effective application and/or for downscaling into economic smaller units for decentralized production.

All reactions can be performed in the laboratory to a certain extent and in many cases with the help of noble metal catalysts [72-74]. Many of these reactions are further performed by nature in its photosynthetic reaction sequences with the help of metallo-enzymes [37] utilizing earth-abundant base metal cores. Also for these reactions we should have a solid understanding generated by bioinorganic chemistry [75].

If we consider that the reaction types of interest (redox reactions) may further be catalyzed by organometallic catalysts for which we have a solid toolbox of designing 
geometric and electronic structure, then we should be certain that we can solve all the required reaction of CEC fairly easily by using the collective fundamental knowledge of 3 different branches of catalysis science.

This conjecture is indeed found in the scientific community $[76,77]$ at present and many publications report on solutions of the CEC issue using the one or another approach indicated above. The large international activity has generated a broad base of conventional and novel solutions to these problems and one would think that CEC is not a serious problem from a purely academic viewpoint. Its realization should be left to industry possibly stimulated by some incentives from politics.

This is, however, not correct if one takes a closer look at the potential solutions for CEC under the conditions discussed in the section "Energy science". Considering the amounts of material to be handled as indicated in Fig. 8 then we need reactions that can be engineered to processes dealing with mass flows of about 250.000 tons of carbon per day alone in Germany. We talk about 50 installations of world-scale dimension conducting the reactions enumerated above.

A typical problem of this sort is the application of reactions 1, 2 describing water splitting through electrolysis (and also photochemically). The reaction can be performed easily in the laboratory and also with multiple devices and catalysts [78] in small dimensions. Hydrogen generation in large quantities is, however, still a massive challenge [79] as the flourishing technological evolution of steam reforming [80] of methane as the today predominant source of hydrogen clearly puts into evidence. In particular, reaction 2 is plagued by enormous stability problems of electrodes [81, 82] and by sluggish kinetics of the underlying 4-electron transfer reaction. Theory has studied the reaction [73, 83] in detail. Experiments reveal that the working electrode is of complex chemical composition [84, 85] with still unknown assignments of function of the various components. Advanced nanotechnology [86-88] tries to minimize the use of precious metals in the functional materials but is confronted with even larger challenges of stability of the system. It is thus fair to say that despite numerous trial applications the critical reaction of water splitting as the basis of all CEC [66], storing electricity in energy carriers is still in a state not ready for use in world-scale dimensions.

An often-made argument in this and other technologies of energy storage is the important role of the economical improvement with larger scale applications. Although this is undeniable one has to be careful with too large hopes in this mechanism of making technology affordable: CEC usually operates not on massively parallel small units (exception accumulators) but on large facilities with complex and large functional units where economy of scale will not change economics by orders of magnitude as it happened for example with PV modules.

The question if CEC is suitable for smaller units where economy of scale [18, 89] would work and with which decentralized systems may be realized is wide open. Such concepts require simple and safe chemical processes that require simple and cheap reactors (no high pressure, low temperatures, low maintenance) $[32,90]$. This is a completely different design philosophy as the one used today where CEC is optimized for overall performance and maximum single parameter efficiency (see discussion above). In the view of the author not enough is done in studying CEC with these two different design concepts as true drivers for any of these technologies are still missing. We do not know if any of the two or more likely both concepts will be successful in future sustainable energy systems. If we consider that infrastructural requirements for central and decentralized systems are different and that such differences exist regionally all over the world (villages in sub-Sahara Africa and in remote regions in the Alps or in the Northern countries, neighborhoods in cities for decentralized solutions, metropolitan areas and industrial complexes or airport hubs as examples for structures that require central infrastructure for energy) then it is hard to decide for or against any of the two concepts.

But we will find it hard to arrive at technology trials with realistic devices and processes under practical field operation conditions, as the resources for such experiments are simply not there. In Germany this can be exemplified with the regulation for the feed-in subsidies which disengages any efforts to store or convert primary electricity. We would need favorable regulations and business models plus the system analytical support [19, 91, 92] in order to stimulate the necessary still large chemical efforts needed to bring forward technologies such as robust redox-flow batteries or decentralized water splitting systems. Multiple nuclei of such activities exist in science and also in innovative industrial activities but the critical mass to bring these to a relevant technology is missing. This impedes also the necessary fundamental science into process details and material concepts required for higher generation devices.

With Fig. 5 we discussed that only a fraction of renewable electricity is available for CEC applications in the near future. To comply with the concept that an optimized economic design will minimize the resistance against realization of a sustainable energy system it is essential that the products of CEC are as valuable as possible. It is thus unlikely that the products of the reactions $1-10$ will be the final stage of CEC. Chemical storage for regeneration of electricity will not be the focus. Rather, the resulting molecules that have stored the energy by reducing the oxidation state of carbon and nitrogen will be 
used for downstream upgrading. The products of reactions $1-10$ are thus the platform molecules discussed with Fig. 7. A combination of the reactions 1, 2, 6, 7 would lead to the formation of methanol as platform molecule. With a relatively simple combination of co-condensation of methanol and formaldehyde a mixture of oligomethylene ethers (OME) [93] can be obtained. These mixtures are perfect blends in diesel or could be used as designer fuels for example in trucking applications making the use of particulate filters obsolete. The reason for this advantage is the absence of $\mathrm{C}-\mathrm{C}$ bonds in the molecule preventing sooting during combustion. The price to be paid is the reduced energy density compared to conventional Diesel that can be tolerated in applications where the volume of a fuel tank is not a critical parameter. Such a scenario is an example of a sequence of CEC transferring renewable energy from the electricity sector into the mobility sector with a substantial economic driver. The transfer is much lager in quantity than with batteries and it stores volatile primary energy for use on demand.

Conditional to such a scenario is the existence of a robust methanol synthesis process working in variable load conditions with $\mathrm{CO}_{2}$ sources clean enough to maintain the high performance of modern engineering concepts. The $\mathrm{MeOH}$ synthesis is equilibrium limited with conversions per pass in the range of $10 \%$ at 50 bar pressure and at around $525 \mathrm{~K}$ where existing catalyst systems operate. Possibilities to reduce the operation temperature to increase the yield per pass compete with strategies to build sequential reactors performing reverse water gas shift reaction and removing reaction water followed by $\mathrm{MeOH}$ synthesis in a $\mathrm{CO}-\mathrm{CO}_{2}$ feed mix exhibiting much more favorable yields. Both options create novel demands on stability and productivity of the $\mathrm{Cu}-\mathrm{ZnO}$ based catalyst. We have good insight into the mechanism of synthesis of $\mathrm{MeOH}$ over bare $\mathrm{Cu}$ surfaces $[94,95]$ and use this as basis for design and performance estimation of practical catalysts. We have also found optimized synthesis routes to catalysts of technical scalability [96-98]. We have developed concepts and synthesis strategies to boost the performance of technical catalysts by adding suitable promoter [99-101] elements. Despite of all these favorable conditions we are not in a position to know if $\mathrm{Cu} /$ $\mathrm{ZnO}$ is the best possible catalyst for this reaction. The underlying reason is that we have discovered that the function of the catalyst is not described adequately by the properties of a copper surface. The long-known "synergy" [102-105] between $\mathrm{Cu}$ and its "support" $\mathrm{ZnO}$ leads to active sites comprising $\mathrm{Cu}, \mathrm{Zn}$ and oxygen in unknown stoichiometric and structural relations. We know that the active catalyst carries an overgrowth of a metastable form of $\mathrm{ZnO}$ [106] sitting on a copper surface that is activated by structural defects creating surface steps [107-109]. It is more than unlikely that such a complicated functional structure of a high-performance catalyst [110] can be described in any meaningful form by a perfect $\mathrm{Cu}$ metal surface model. We need to disentangle the intricacy of this catalyst in order to see which improvement potential with respect to activity, insensitivity to contaminations in the $\mathrm{CO}_{2}$ feed and stability [111] against in-stationary operation can be achieved with this catalyst that was optimized by trial-and error for decades for a mode of operation of $\mathrm{MeOH}$ synthesis that is sub-optimal for integration $\mathrm{MeOH}$ in a CEC strategy of an energy system.

Another route of CEC into solid storage is also indicated in Fig. 7. Using solid-state systems to store free electrons or hydrogen carries the large advantage that no molecular energy carrier is converted into $\mathrm{CO}_{2}$ requiring collection and reduction. Such solid-state systems are thus clean and often stable in their performance. Their large dis-advantage is that large masses of solids have to be used to accommodate relatively few energy carriers. This is no problem in small devices. In mobility applications the energy density is a problem and in stationary applications the material consumption and price of such storage systems are problematic. Nevertheless, there is still an enormous need for improvement of materials and processes [51, 112-114] and we also need much deeper insight into the complex interfacial kinetics of such reactions. Accumulators, redox-flow batteries and reversible hydrogen storage systems are perfect examples of CEC with solids.

A common underlying issue with all reactions enumerated above is the frequent use of noble metal catalysts. There exist the competing opinions that this is no problem as long as we fully recycle the precious metal catalyst after deactivation. The opposite school of thought considers avoiding these critical but not really rare elements in energy CEC applications for scientific and geo-political reasons and postulate [115] that earth-abundant 3-d and 4-d metals are essential ingredients in sustainable energy CEC technologies.

\section{Conclusions}

Sustainable energy systems can have multiple structures and require thus multiple technological elements. For a long time into the future they will be hybrid between fossil and renewable primary energy carriers. Perceptions that renewable energy is a drop-in substitute for fossil or nuclear energy and that we have all technologies at hand that we need for the transformation of fossil into sustainable systems are incorrect. Misleading are also the devaluation of fossil energy carriers as "dirty" and the quest for radical decarbonisation of the energy system. 
CEC is a critical enabling family of technologies that can support the sustainability of energy systems by closing the $\mathrm{CO}_{2}$ cycle through its reduction into "solar" energy carriers. This is, however, only possible if the dimension of this operation is brought into relation of the $\mathrm{CO}_{2}$ generation from energy applications. The multitude of chemical structures reflects itself in a multitude of CEC solutions. Small molecule transformations stand at the beginning of value chains transferring renewable energy into stored chemical energy for use on demand.

CEC comprises direct storage of electricity or heat in solid-state devices as one family of concepts and the transformation of $\mathrm{CO}_{2}$ or nitrogen with reducing equivalents from renewable sources (water splitting to hydrogen) into molecular energy carriers. Advantages of the former are the clean reversible operation, no emissions and fast response times. Battery science and thermo-kinetics are typical science disciplines dealing with such systems.

The latter process leads to bulk amounts of energy carrier materials and can thus store and transport large amounts of renewable electricity for infinite times. It is however, slow, requires likely large infrastructures and requires closing of the mass flow of $\mathrm{CO}_{2}$. The sciences of catalysis in physical chemistry, theory and chemical engineering are core disciplines dealing with these challenges.

The dimension and the broad distribution of CEC in sustainable energy systems make it a pre-requisite to design the processes and materials on the basis of functional knowledge and to abstain from the empirical approaches used mostly so far. Only the rational approach can guarantee that a global and systemic optimal solution has been found ending the scientific search for solutions of a given CEC challenge. As in many technologies also in CEC the empirical development leads the way to application and roll-out. More than in other areas of technology this phase must be followed by the rational evolution. In energy system transformation a key problem exists besides the dimension of the operation in time and resources, that the sustainable technologies are complex and intrinsically expensive. They have to compete with traditional and cheap fossil technologies or with nuclear technologies where external cost is transferred for non-energy reasons to society. These conditions call even more for a strategy in which the optimum of a technology is found on the basis of knowledge and insight.

A strong base of energy science in fundamental understanding and scalable material synthesis is further prerequisite for fulfilling the enormous societal expectations on chemistry (the old trouble maker with environmental pollution) coming now with the sustainable energy theme. This firm rooting in fundamentals needs to be continued in co-operative efforts of critical dimension to transfer the initial insight into true technologies ready for use in industrial context. As sustainable energy helps the target of climate protection most outside Germany, strong industrial engagement and flexible solution concepts are needed to finally bring the fruits of fundamental CEC to bear. In this area not only multiple scientific challenges are still unsolved but also new forms of trustful and stable collaboration across institutions and industries is required. Finally, energy systems are for societies. Their design without the involvement of society accepting its technologies on the basis of understanding and non-ideological discourse will lead to problems named as "acceptance challenge". An important element of a strategy against this effect is the open participation of society through social science and societal organizations in the finding process of science and technologies. The author sees much demand for establishing role models and success stories that lead the way to a broad alliance for sustainable energy science. The presently observed risk-adverse, ideological and inward-oriented approach to energy science from many stakeholders is not a good basis for rapidly solving one of the largest challenges in modern history.

Acknowledgments Open access funding provided by Max Planck Society (Fritz-Haber-Institute of the Max Planck Society).

Open Access This article is distributed under the terms of the Creative Commons Attribution 4.0 International License (http://crea tivecommons.org/licenses/by/4.0/), which permits unrestricted use, distribution, and reproduction in any medium, provided you give appropriate credit to the original author(s) and the source, provide a link to the Creative Commons license, and indicate if changes were made.

\section{References}

1. Schlogl R (2010) The role of chemistry in the energy challenge. Chemsuschem 3:209-222

2. Schlögl R (2015) Heterogeneous catalysis. Angew Chem Int Ed 54:3465-3520

3. Sanchez M, Cadavid F, Amell A (2013) Experimental evaluation of a $20 \mathrm{~kW}$ oxygen enhanced self-regenerative burner operated in flameless combustion mode. Appl Energy 111:240-246

4. Dennis JS, Scott SA (2010) In situ gasification of a lignite coal and $\mathrm{CO}_{2}$ separation using chemical looping with a $\mathrm{Cu}$-based oxygen carrier. Fuel 89:1623-1640

5. Berg M, Johansson EM, Jaras SG (2000) Catalytic combustion of low heating value gas mixtures: comparison between laboratory and pilot scale tests. Catal Today 59:117-130

6. Guelder OL, Intasopa G, Joo HI, Mandatori PM, Bento DS, Vaillancourt ME (2011) Unified behaviour of maximum soot yields of methane, ethane and propane laminar diffusion flames at high pressures. Combust Flame 158:2037-2044

7. Law CK, Kwon OC (2004) Effects of hydrocarbon substitution on atmospheric hydrogen-air flame propagation. Int $\mathrm{J}$ Hydrog Energy 29:867-879

8. Richter H, Howard JB (2002) Formation and consumption of single-ring aromatic hydrocarbons and their precursors in 
premixed acetylene, ethylene and benzene flames. Phys Chem Chem Phys 4:2038-2055

9. Kasper M, Sattler K, Siegmann K, Matter U, Siegmann HC (1999) The influence of fuel additives on the formation of carbon during combustion. J Aerosol Sci 30:217-225

10. Schlögl R (2015) The revolution continues: energiewende 2.0. Angew Chem Int Ed 54:4436-4439

11. Zoeller JR (2009) Eastman chemical company's "Chemicals from Coal" program: the first quarter century. Catal Today 140:118-126

12. Marsh H, O'Hair TE, Reed R (1965) Oxidation of carbons and graphites by atomic oxygen: an electron microscope study of surface changes. Trans Faraday Soc 61:285-293

13. van Krevelen DW (1982) Fuel 61:786-790

14. Haenel MW (1992) Recent progress in coal structure research. Fuel 71:1211-1223

15. Partington JR (1919) On the oxidation of coal. Chem News J Phys Sci 118:50-51

16. Wheeler RV (1918) The oxidation and ignition of coal. J Chem Soc 113:945-955

17. Muller A (2009) Sustainable agriculture and the production of biomass for energy use. Clim Change 94:319-331

18. Asif M, Muneer T (2007) Energy supply, its demand and security issues for developed and emerging economies. Renew Sustain Energy Rev 11:1388-1413

19. Barreto L, Makihira A, Riahi K (2003) The hydrogen economy in the 21 st century: a sustainable development scenario. Int $\mathbf{J}$ Hydrog Energy 28:267-284

20. Kemp R (1994) Technology and the transition to environmental sustainability - the problem of technological regime shifts. Futures 26:1023-1046

21. Schlögl R (2012) The role of chemistry in the energy challenge. In: Renn J (ed) The globalization of knowledge in history. Wiley, New York, p 868

22. Herrera AM, Pesavento E (2009) Oil price shocks, systematic monetary policy, and the "Great Moderation". Macroecon Dyn 13:107-137

23. Doroodian K, Boyd R (2003) The linkage between oil price shocks and economic growth with inflation in the presence of technological advances: a CGE model. Energy Policy 31:989-1006

24. Olah GA, Goeppert A, Prakash GKS (2009) Chemical recycling off carbon dioxide to methanol and dimethyl ether: from greenhouse gas to renewable environmentally carbon neutral fuels and synthetic hydrocarbons. J Org Chem 74:487-498

25. Olah GA (2005) Beyond oil and gas: the methanol economy. Angew Chem Int Ed 44:2636-2639

26. Asinger F (1985) Methanol, Chemie-und Energierohstoff. Springer, Berlin

27. Song CS (2006) Global challenges and strategies for control, conversion and utilization of $\mathrm{CO}_{2}$ for sustainable development involving energy, catalysis, adsorption and chemical processing. Catal Today 115:2-32

28. Centi G, Perathoner S (2009) Opportunities and prospects in the chemical recycling of carbon dioxide to fuels. Catal Today 148:191-205

29. Thomas JM (2014) Reflections on the topic of solar fuels. Energy Environ Sci 7:19-20

30. Lubitz W, Reijerse EJ, Messinger J (2008) Solar water-splitting into $\mathrm{H}-2$ and O-2: design principles of photosystem II and hydrogenases. Energy Environ Sci 1:15-31

31. Kanan MW, Surendranath Y, Nocera DG (2009) Cobalt-phosphate oxygen-evolving compound. Chem Soc Rev 38:109-114

32. Lewis NS, Nocera DG (2006) Powering the planet: chemical challenges in solar energy utilization. Proc Natl Acad Sci USA 103:15729-15735
33. Wagner F (2014) Electricity by intermittent sources: an analysis based on the German situation 2012. Eur Phys J Plus 129:1-18

34. Ghanadan R, Koomey JG (2005) Using energy scenarios to explore alternative energy pathways in California. Energy Policy 33:1117-1142

35. Behrendt F, Renn O, Schlögl R, Schüth F, Umbach E, Wagner H-J (2011) Ad hoc-Stellungnahme: Energiepolitische und forschungspolitische Empfehlungen nach den Ereignissen in Fukushima, in: Stellungnahme der Nationalen Akademie der Wissenschaften Leopoldina, Deutsche Akademie der Naturforscher Leopoldina-Nationale Akademie der Wissenschaften, Halle(Saale), p. 32

36. Energieforschungskonzept (2009) In: Leopoldina

37. Gust D, Moore TA, Moore AL (2009) Solar fuels via artificial photosynthesis. Acc Chem Res 42:1890-1898

38. Chopra KL, Paulson PD, Dutta V (2004) Thin-film solar cells: an overview. Prog Photovolt 12:69-92

39. Goetzberger A, Hebling C, Schock HW (2003) Photovoltaic materials, history, status and outlook. Mater Sci Eng R Rep 40:1-46

40. Shah A, Torres P, Tscharner R, Wyrsch N, Keppner H (1999) Photovoltaic technology: the case for thin-film solar cells. Science 285:692-698

41. Oregan B, Gratzel M (1991) A low-cost, high-efficiency solarcell based on dye-sensitized colloidal $\mathrm{TiO}_{2}$ films. Nature 353:737-740

42. Schlögl R (2011) Chemistry's role in regenerative energy. Angew Chem Int Ed 50:6424-6426

43. Guer TM (2013) Critical review of carbon conversion in "carbon fuel cells". Chem Rev 113:6179-6206

44. Falkowski P, Scholes RJ, Boyle E, Canadell J, Canfield D, Elser J, Gruber N, Hibbard K, Hogberg P, Linder S, Mackenzie FT, Moore B, Pedersen T, Rosenthal Y, Seitzinger S, Smetacek V, Steffen W (2000) The global carbon cycle: a test of our knowledge of earth as a system. Science 290:291-296

45. Sims REH, Mabee W, Saddler JN, Taylor M (2010) An overview of second generation biofuel technologies. Bioresour Technol 101:1570-1580

46. Barber J (2009) Photosynthetic energy conversion: natural and artificial. Chem Soc Rev 38:185-196

47. Rinaldi R, Schuth F (2009) Design of solid catalysts for the conversion of biomass. Energy Environ Sci 2:610-626

48. Smeets EMW, Faaij APC, Lewandowski IM, Turkenburg WC (2007) A bottom-up assessment and review of global bio-energy potentials to 2050. Prog Energy Combust Sci 33:56-106

49. Chheda J, Huber G, Dumesic J (2007) Liquid-phase catalytic processing of biomass-derived oxygenated hydrocarbons to fuels and chemicals. Angew Chem Int Ed 46:7164-7183

50. Gooch DJ (2000) Materials issues in renewable energy power generation. Int Mater Rev 45:1-14

51. Su DS, Schlögl R (2010) Nanostructured carbon materials for electrochemical energy storage applications. ChemSusChem 3:136-168

52. Hu Y-S, Liu X, Müller J-O, Schlögl R, Maier J, Su DS (2009) Synthesis and electrode performance of nanostructured $\mathrm{V}_{2} \mathrm{O}_{5}$ by using a carbon tube-in-tube as a nanoreactor and an efficient mixed-conducting network. Angew Chem Int Ed 48:210-214

53. Thomas A, Fischer A, Goettmann F, Antonietti M, Muller JO, Schlogl R, Carlsson JM (2008) Graphitic carbon nitride materials: variation of structure and morphology and their use as metal-free catalysts. J Mater Chem 18:4893-4908

54. Singh A, Spiccia L (2013) Water oxidation catalysts based on abundant 1st row transition metals. Coord Chem Rev 257:2607-2622 
55. Rossmeisl J, Dimitrievski K, Siegbahn P, Norskov JK (2007) Comparing electrochemical and biological water splitting. J Phys Chem C 111:18821-18823

56. Scrosati B, Garche J (2010) Lithium batteries: Status, prospects and future. J Power Sources 195:2419-2430

57. Marnellos G, Stoukides M (2004) Catalytic studies in electrochemical membrane reactors. Solid State Ionics 175:597-603

58. Haile SM (2003) Fuel cell materials and components. Acta Mater 51:5981-6000

59. Sasaki K, Maier J (1999) Low-temperature defect chemistry of oxides. I. General aspects and numerical calculations. J Appl Phys 86:5422-5433

60. Rady AC, Giddey S, Badwal SPS, Ladewig BP, Bhattacharya S (2012) Review of fuels for direct carbon fuel cells. Energy Fuels 26:1471-1488

61. Li M, Rao AD, Brouwer J, Samuelsen GS (2010) Design of highly efficient coal-based integrated gasification fuel cell power plants. J Power Sources 195:5707-5718

62. Tributsch H (2008) Photovoltaic hydrogen generation. Int J Hydrog Energy 33:5911-5930

63. Klaus S, Lehenmeier MW, Anderson CE, Rieger B (2011) Recent advances in $\mathrm{CO}_{2}$ /epoxide copolymerization-new strategies and cooperative mechanisms. Coord Chem Rev 255:1460-1479

64. Berntsen T, Fuglestvedt J, Myhre G, Stordal F, Berglen TF (2006) Abatement of greenhouse gases: does location matter? Clim Change 74:377-411

65. MacLean HL, Lave LB (2003) Evaluating automobile fuel/ propulsion system technologies. Prog Energy Combust Sci 29:1-69

66. Sharif A, Almansoori A, Fowler M, Elkamel A, Alrafea K (2014) Design of an energy hub based on natural gas and renewable energy sources. Int J Energy Res 38:363-373

67. Bundesregierung, Energiekonzept (2010)

68. Romm J (2006) The car and fuel of the future. Energy Policy 34:2609-2614

69. Clement-Nyns K, Haesen E, Driesen J (2010) The impact of charging plug-in hybrid electric vehicles on a residential distribution grid. IEEE Trans Power Syst 25:371-380

70. Kaundinya DP, Balachandra P, Ravindranath NH (2009) Gridconnected versus stand-alone energy systems for decentralized power-a review of literature. Renew Sustain Energy Rev 13:2041-2050

71. Hoffert MI, Caldeira K, Benford G, Criswell DR, Green C, Herzog H, Jain AK, Kheshgi HS, Lackner KS, Lewis JS, Lightfoot HD, Manheimer W, Mankins JC, Mauel ME, Perkins LJ, Schlesinger ME, Volk T, Wigley TML (2002) Advanced technology paths to global climate stability: energy for a greenhouse planet. Science 298:981-987

72. Vojvodic A, Norskov JK, Abild-Pedersen F (2014) Electronic structure effects in transition metal surface chemistry. Top Catal $57: 25-32$

73. Viswanathan V, Hansen HA, Rossmeisl J, Norskov JK (2012) Universality in oxygen reduction electrocatalysis on metal surfaces. ACS Catalysis 2:1654-1660

74. Wang SG, Temel B, Shen JA, Jones G, Grabow LC, Studt F, Bligaard T, Abild-Pedersen F, Christensen CH, Norskov JK (2011) Universal Bronsted-Evans-Polanyi relations for $\mathrm{C}-\mathrm{C}$, $\mathrm{C}-\mathrm{O}, \mathrm{C}-\mathrm{N}, \mathrm{N}-\mathrm{O}, \mathrm{N}-\mathrm{N}$, and $\mathrm{O}-\mathrm{O}$. Dissoc React Catal Lett 141:370-373

75. Cox N, Pantazis DA, Neese F, Lubitz W (2013) Biological water oxidation. Acc Chem Res 46:1588-1596

76. Federsel C, Ziebart C, Jackstell R, Baumann W, Beller M (2012) Catalytic hydrogenation of carbon dioxide and bicarbonates with a well-defined cobalt dihydrogen complex. Chemistry 18:72-75

77. Federsel C, Jackstell R, Beller M (2010) State-of-the-art catalysts for hydrogenation of carbon dioxide. Angew Chem Int Ed 49:6254-6257
78. Gratzel M (1981) Artificial photosynthesis-water cleavage into hydrogen and oxygen by visible-light. Acc Chem Res 14: 376-384

79. Gahleitner G (2013) Hydrogen from renewable electricity: an international review of power-to-gas pilot plants for stationary applications. Int J Hydrog Energy 38:2039-2061

80. Xu Y, Lausche AC, Wang SG, Khan TS, Abild-Pedersen F, Studt F, Norskov JK, Bligaard T (2013) In silico search for novel methane steam reforming catalysts. New J Phys 15:125021

81. Galeano C, Meier JC, Peinecke V, Bongard H, Katsounaros I, Topalov AA, Lu A, Mayrhofer KJJ, Schueth F (2012) Toward highly stable electrocatalysts via nanoparticle pore confinement. J Am Chem Soc 134:20457-20465

82. Topalov AA, Katsounaros I, Auinger M, Cherevko S, Meier JC, Klemm SO, Mayrhofer KJJ (2012) Dissolution of platinum: limits for the deployment of electrochemical energy conversion ? Angew Chem Int Ed 51:12613-12615

83. Rossmeisl J, Qu ZW, Zhu H, Kroes GJ, Norskov JK (2007) Electrolysis of water on oxide surfaces. J Electroanal Chem 607:83-89

84. Su H-Y, Gorlin Y, Man IC, Calle-Vallejo F, Norskov JK, Jaramillo TF, Rossmeisl J (2012) Identifying active surface phases for metal oxide electrocatalysts: a study of manganese oxide bifunctional catalysts for oxygen reduction and water oxidation catalysis. Phys Chem Chem Phys 14:14010-14022

85. Arrigo R, Hävecker M, Schuster ME, Ranjan C, Stotz E, KnopGericke A, Schlögl R (2013) In situ study of the gas-phase electrolysis of water on platinum by NAP-XPS. Angew Chem Int Ed 52:11660-11664

86. Reier T, Teschner D, Lunkenbein T, Bergmann A, Selve S, Kraehnert R, Schlögl R, Strasser P (2014) Electrocatalytic oxygen evolution on iridium oxide: uncovering catalyst-substrate interactions and active iridium oxide species. J Electrochem Soc 161:F876-F882

87. Johnson B, Girgsdies F, Weinberg G, Rosenthal D, Knop-Gericke A, Schloegl R, Reier T, Strasser P (2013) Suitability of simplified (Ir, Ti)O-x films for characterization during electrocatalytic oxygen evolution reaction. J Phys Chem C 117: 25443-25450

88. Koh S, Strasser P (2007) Electrocatalysis on bimetallic surfaces: modifying catalytic reactivity for oxygen reduction by voltammetric surface dealloying. J Am Chem Soc 129:12624

89. Grubler A, Nakicenovic N, Victor DG (1999) Dynamics of energy technologies and global change. Energy Policy 27: 247-280

90. Michael H, Bediako DK, Nocera DG (2014) A functionally stable manganese oxide oxygen evolution catalyst in acid. J Am Chem Soc 136:6002-6010

91. Riahi K, Gruebler A, Nakicenovic N (2007) Scenarios of longterm socio-economic and environmental development under climate stabilization. Technol Forecast Soc Chang 74:887-935

92. Lewis NS (2007) Toward cost-effective solar energy use. Science 315:798-801

93. Burger J, Strofer E, Hasse H (2013) Production process for diesel fuel components poly(oxymethylene) dimethyl ethers from methane-based products by hierarchical optimization with varying model depth. Chem Eng Res Des 91:2648-2662

94. Yang Y, Mims CA, Mei DH, Peden CHF, Campbell CT (2013) Mechanistic studies of methanol synthesis over $\mathrm{Cu}$ from $\mathrm{CO} /$ $\mathrm{CO}_{2} / \mathrm{H}_{2} / \mathrm{H}_{2} \mathrm{O}$ mixtures: the source of $\mathrm{C}$ in methanol and the role of water. J Catal 298:10-17

95. Zhao Y-F, Yang Y, Mims C, Peden CHF, Li J, Mei D (2011) J Catal 281:199-211

96. Schumann J, Lunkenbein T, Tarasov A, Thomas N, Schlögl R, Behrens M (2014) Synthesis and characterisation of a highly active $\mathrm{Cu} / \mathrm{ZnO}: \mathrm{Al}$ catalyst. ChemCatChem 6:2889-2897 
97. Kozlowski JT, Behrens M, Schlögl R, Davis RJ (2013) Influence of the precipitation method on acid-base-catalyzed reactions over Mg-Zr mixed oxides. ChemCatChem 5:1989-1997

98. Behrens M, Schlögl R (2013) How to prepare a good $\mathrm{Cu} / \mathrm{ZnO}$ catalyst or the role of solid state chemistry for the synthesis of nanostructured catalysts. Z Anorg Allg Chem 639:2683-2695

99. Zander S, Kunkes EL, Schuster ME, Schumann J, Weinberg G, Teschner D, Jacobsen N, Schlögl R, Behrens M (2013) The role of the oxide component in the development of copper composite catalysts for methanol synthesis. Angew Chem Int Ed 52: 6536-6540

100. Behrens M, Zander S, Kurr P, Jacobsen N, Senker J, Koch G, Ressler T, Fischer RW, Schlögl R (2013) Performance improvement of nanocatalysts by promoter-induced defects in the support material: methanol synthesis over $\mathrm{Cu} / \mathrm{ZnO}$ :Al. J Am Chem Soc 135:6061-6068

101. Behrens M, Lolli G, Muratova N, Kasatkin I, Hävecker M, Naumann d'Alnoncourt R, Storcheva O, Köhler K, Muhler M, Schlögl R (2013) The effect of Al-doping on $\mathrm{ZnO}$ nanoparticles applied as catalyst support. Phys Chem Chem Phys 15:1374-1381

102. Kuld S, Conradsen C, Moses PG, Chorkendorff I, Sehested J (2014) Quantification of Zinc Atoms in a Surface Alloy on Copper in an Industrial-Type Methanol Synthesis Catalyst. Angewandte Chemie-International Edition 53:5941-5945

103. Frenzel J, Marx D (2014) Methanol synthesis on ZnO(000(1)over-bar). IV. Reaction mechanisms and electronic structure. J Chem Phys 141:124710

104. Nakamura J, Choi Y, Fujitani T (2003) On the issue of the active site and the role of $\mathrm{ZnO}$ in $\mathrm{Cu} / \mathrm{ZnO}$ methanol synthesis catalysts. Top Catal 22:277-285

105. Ovesen CV, Clausen BS, Schiotz J, Stoltze P, Topsoe H, Norskov JK (1997) Kinetic implications of dynamical changes in catalyst morphology during methanol synthesis over $\mathrm{Cu} / \mathrm{ZnO}$ catalysts. J Catal 168:133-142

106. Lunkenbein T, Schumann J, Behrens M, Willinger MG (2015) Formation of a $\mathrm{ZnO}$ overlayer in industrial $\mathrm{Cu} / \mathrm{ZnO} / \mathrm{Al}_{2} \mathrm{O}_{3}$ cat- alysts induced by strong metal-support interaction. Angew Chem Int Ed 127:4627-4631

107. Kandemir T, Kasatkin I, Girgsdies F, Zander S, Kühl S, Tovar M, Schlögl R, Behrens M (2014) Microstructural and defect analysis of metal nanoparticles in functional catalysts by diffraction and electron microscopy: the $\mathrm{Cu} / \mathrm{ZnO}$ catalyst for methanol synthesis. Top Catal 57:188-206

108. Fichtl MB, Schumann J, Kasatkin I, Jacobsen N, Behrens M, Schlögl R, Muhler M, Hinrichsen O (2014) Counting of oxygen defects versus metal surface sites in methanol synthesis catalysts by different probe molecules. Angew Chem Int Ed 53: 7043-7047

109. Kandemir T, Girgsdies F, Hansen TC, Liss K-D, Kasatkin I, Kunkes EL, Wowsnick G, Jacobsen N, Schlögl R, Behrens M (2013) In situ study of catalytic processes: neutron diffraction of a methanol synthesis catalyst at industrially relevant pressure. Angew Chem Int Ed 52:5166-5170

110. Behrens M, Studt F, Kasatkin I, Kühl S, Hävecker M, AbildPedersen F, Zander S, Girgsdies F, Kurr P, Kniep B-L, Tovar M, Fischer RW, Nørskov JK, Schlögl R (2012) The active site of methanol synthesis over $\mathrm{Cu} / \mathrm{ZnO} / \mathrm{Al}_{2} \mathrm{O}_{3}$ industrial catalysts. Science 336:893-897

111. Twigg MV, Spencer MS (2003) Deactivation of copper metal catalysts for methanol decomposition, methanol steam reforming and methanol synthesis. Top Catal 22:191-203

112. Liu C, Li F, Ma LP, Cheng HM (2010) Advanced materials for energy storage. Adv Mater 22:E28

113. Girishkumar G, McCloskey B, Luntz AC, Swanson S, Wilcke W (2010) Lithium-air battery: promise and challenges. J Phys Chem Lett 1:2193-2203

114. Christensen CH, Johannessen T, Sorensen RZ, Norskov JK (2006) Towards an ammonia-mediated hydrogen economy? Catal Today 111:140-144

115. Faber MS, Jin S (2014) Earth-abundant inorganic electrocatalysts and their nanostructures for energy conversion applications. Energy Environ Sci 7:3519-3542 